Die unmittelbar nach operativen Eingriffen im Zwischenhirnbereich von Anuren beobachtete, über längere Zeit andauernde Pigmentausbreitung ${ }^{1-8}$ steht im Gegensatz zu den hier mitgeteilten Befunden. Die Unterschiede lassen sich wie folgt deuten: Adulte $R$. temporaria überlebten die Epiphysektomie höchstens 3 Tage, während derer sie permanent dunkel blieben ${ }^{s}$. Die histologische Aufarbeitung der Gehirne dieser Tiere ergab, dass stets das $Z$ wischenhirndach perforiert war, was ein Ausfliessen des Liquor cerebrospinalis zur Folge haben musste. Möglicherweise wurde unter diesen veränderten Verhältnissen die Hypophyse zur intensiven MSH-Produktion und -Freigabe angeregt. Nur wenn sich nach Verschluss der Offnung im Ventrikel Druck und Zusammensetzung des Liquors normalisieren können, vermögen die Chromatophoren wieder auf Umweltreize zu reagieren. Dieser Deutung entsprechen auch die Befunde am Krallenfrosch 1 .

Alle Untersuchungen über die Beteiligung der Epiphyse am Farbwechsel der Amphibien wurden bisher mit Tieren durchgeführt, deren Lateralaugen intakt waren. Dabei liess sich eine funktionelle Verknüpfung von Epiphyse und Melanophoren noch nicht befriedigend nachweisen. Offen bleibt, ob die Epiphyse beim augenunabhängigen tagesperiodischen Farbwechsel eine Rolle spielt.

Summary. Three epiphysectomized adult Rana esculenta became pale when transferred from a black to a white background. Histological examination of the midbrain showed that the pineal body was entirely destroyed and no regeneration had taken place.

\section{H. BogENSCHÜTZ}

Abteilung für Experimentelle Ophthalmologie (II. Physiol. Abt.) des W. G. Kerckhoff-Instituts der Max-PlanckGesellschaft, 635 Bad Nauheim (Deutschland), 2. Juni 1967.

\title{
Chlorophyll Synthesis in Tobacco Callus: Interaction of Sugar and Kinetin
}

StexLER and LAETSCH $^{1}$ demonstrated that kinetin was essential for the maturation of chloroplasts in growing cultures of tobacco tissue. This phenomenon has been investigated further in order to provide more information on the specificity of kinetin. The experiments cited above used explants of dark-grown tissue which were placed in the light on a growth-promoting medium. The initial experiments in the series reported here used pieces of callus (1-2 g) which had grown in the dark from small explants. These pieces were placed in individual culture tubes in continuous light on media which would not support growth because of the absence of auxin, vitamins, and amino acids. The synthesis of chlorophyll by these cultures on different media was variable, and it was found that the variability was due to sucrose being carried over in the tissue from the previous medium. This problem was solved by growing the tissue in the dark on a medium $^{2}$ without kinetin, and by transferring the tissue to a plain agar medium 3 days before exposure to light. A longer starvation period resulted in unhealthy tissue.

At the end of the starvation period, the pieces of tissue were transferred to the following media: Complete salt solution (salts); salts + sucrose $5.0 \mathrm{~g} / \mathrm{l}$; salts + kinetin $0.5 \mathrm{mg} / 1$; salts + sucrose + kinetin. The callus was harvested after 1 week in the light and chlorophyll was determined $^{3}$. Chlorophyll values for a typical experiment are shown in the Table.

\section{Salts}

Salts + kinetin

Salts + sucrose

Salts + sucrose + kinetin
The difference in chlorophyll content between 2 of the treatments is not significant. The results clearly demonstrate that kinetin alone will not support chlorophyll synthesis unless sucrose is present.

The inverse relation between tissue growth and chloroplast development is discussed by LAETsch and STET$L E R^{4}$, and the present results suggest the same relationship. The callus can grow without exogenous cytokinin, so it is reasonable to suspect that the tissue produces small amounts of endogenous cytokinins. It is felt that the tissue utilizes this supply for growth and cytokinins are limiting for chloroplast development. When a large piece of tissue, such as that used in these experiments, is maintained on a medium which will not support growth the endogenous cytokinin is available for chloroplast development. The experiments show that sucrose is necessary as an energy source for this process ${ }^{5}$.

Zusammenfassung. Kinetin ist für die Chlorophyllsynthese von wachsendem Tabak-Kallusgewebe notwendig. Nicht wachsendes Kallusgewebe ergrünt auch ohne Kinetin, sofern dem Medium Saccharose als Energiequelle zugesetzt wird. Hier stehen möglicherweise endogene Cytokinine für die Chlorophyllsynthese zur Verfügung.

\section{R. Boasson and W. M. LaEtsch}

Department of Botany, University of California, Berkeley (Califormia 94720, USA), 3rd July 1967.
1 D. A. Stetlef and W. M. LAetsch, Science 749,1387 (1965).

- T. Murashige and F. Skoog, Physiologia Pl. 15, 473 (1962).

- D. I. Arnon, Pl. Physiol., Lancaster 24, 1 (1949).

4 W. M. LAetsch and D. A. Stetler, Am. J. Bot. 52, 798 (1965).

- This work was supported by National Science Foundation Grant No. GB 4042 . 